\title{
Research Paper Socio-economic conditions of Bt cotton growers across different farm size holders in northern transitional zone of Karnataka
}

See end of the paper for authors' affiliations

Correspondence to : P. B. GAMANAGATTI Department of Agricultural Economics, University of Agricultural Sciences, DHARWAD (KARNATAKA) INDIA

Email: pavanecon@ gmail.com

Paper History :

Received : 30.12.2015,

Revised : 01.08.2016;

Accepted : 24.08 .2016
AbSTRACT : Karnataka is one of the nine major Bt cotton-growing states in the country. Northern transitional zone is the major cotton growing zone of Karnataka i.e. 40.19 per cent of the total cotton area of Karnataka. It focused on the socio-economic characteristics of Bt cotton farmers and the economics of Bt cotton production under different farm sizes. Two taluks having highest cotton area were selected from the zone for study. The study was conducted with primary data collected entirely based on a multi stage sampling technique from $180 \mathrm{Bt}$ cotton growing farmers. The study pertained to the agricultural year 2011. The total variable cost of Bt cotton was Rs. 22192.15 where, large farmers incurred high cost i.e. Rs. 23256.85. The total cost of Bt cotton was Rs. 30920.56 and it was high in large farmers Rs. 32723.90. The net return in Bt cotton was Rs. 79456.36 and net returns were seen high in case of large farmers Rs. 84677.90. The yield per ha was 24.98 qtls and medium farmers got high yields i.e. $25.54 \mathrm{qtls}$. Bt cotton technology has positive impact on socio- economic status of farmers by increase in yield and reducing cost on inputs thereby increase in income and also standard of living.

KeY Words : Bt cotton, Yield, Small farmer, Medium farmer, Large farmer

How To Cite This PAper : Gamanagatti, P.B. and Dodamani, M. T. (2016). Socio-economic conditions of Bt cotton growers across different farm size holders in northern transitional zone of Karnataka. Internat. Res. J. Agric. Eco. \& Stat., 7 (2) : 223-227, DOI : 10.15740/HAS/IRJAES/7.2/223-227. 